\title{
THE FREQUENCY OF PERIPHERAL NEUROPATHY IN A GROUP OF HIV POSITIVE PATIENTS IN BRAZIL
}

\author{
Claudia Zanetti, Gilberto M. Manzano, Alberto A. Gabbai
}

\begin{abstract}
Peripheral neuropathy is a common neurological complication occurring in asymptomatic and symptomatic stages of HIV infection. The most common syndromes are distal symmetric polyneuropathy, inflammatory demielinating polyneuropathy, poliradiculopathy, mononeuropathy, mononeuropathy multiplex and autonomic neuropathy. Purpose: To evaluate the frequency of peripheral neuropathy in a group of HIV seropositive outpatients in São Paulo, Brazil. Method: Over a period of 17 months, 49 HIV + patients where evaluated clinically. Laboratory analysis and electroneuromyography were requested to all patients. Results: Thirty four $(69.4 \%)$ of the 49 patients had the diagnosis of peripheral neuropathy established on clinical grounds. The most common sign was impairment $(97.1 \%)$ of sensibility. Thirteen $(33.3 \%)$ of the 39 that were subjected to electroneuromyography had features of peripheral neuropathy, being a sensitive-motor axonal neuropathy the most common. No abnormalities were found in the laboratory analysis performed in 42 patients, except in four who had VDRL positive. Conclusion: A peripheral neuropathy was frequently found upon clinical examination in our group of HIV positive individuals.
\end{abstract}

KEY WORDS: peripheral neuropathy, HIV, AIDS.

\begin{abstract}
Freqüência da neuropatia periférica no Brasil em um grupo de pacientes HIV positivo
RESUM 0 - A neuropatia periférica é complicação neurológica comum, podendo ocorrer nas fases assintomáticas e sintomáticas da infecção pelo vírus da imunodeficiência humana (HIV). As síndromes mais comuns são a polineuropatia distal simétrica, polineuropatia desmielinizante inflamatória, polirradiculopatia, mononeuropatia, mononeuropatia múltipla e neuropatia autonômica. Objetivo: Avaliar a freqüência da neuropatia periférica em um grupo de pacientes HIV positivo em São Paulo, Brasil. M étodo: Em um período de 17 meses, foram avaliados clinicamente 49 pacientes HIV positivos. Foram solicitados exames laboratoriais e eletroneuromiografia (ENMG) para todos os pacientes. Resultados: Foi estabelecido o diagnóstico clínico de neuropatia periférica em $34(69,4 \%)$ dos 49 pacientes. 0 sinal neurológico mais comum foi a alteração da sensibilidade $(97,1 \%)$. Treze $(33,3 \%)$ dos 39 pacientes que realizaram a ENM G tiveram o diagnóstico de neuropatia periférica, sendo a neuropatia sensitivo-motora axonal 0 achado mais comum. Não foram encontradas alterações significativas nos exames laboratoriais (42 pacientes realizaram os exames), com exceção de quatro pacientes em que o VDRL foi positivo. Conclusão: A neuropatia periférica foi um achado freqüente no grupo de pacientes HIV positivo estudados clinicamente.
\end{abstract}

PALAVRAS-CHAVE: neuropatia periférica, HIV, SIDA.

The acquired immunodeficiency syndrome (AIDS) was first described in 1981. At that time it was reported the occurrence of an uncommon opportunistic infection caused by Pneumocystis carinni in a previously healthy young homosexual man ${ }^{1}$. Neurological disorders in HIV patients were first reported in $1982^{2}$. Peripheral neuropathy is a common neurological complication associated with human immunodeficiency virus type 1 (HIV-1) infection, occurring in asymptomatic and symptomatic individuals ${ }^{3-5}$ and it can be the first manifestation of the disease ${ }^{6}$. The peripheral neuropathy syndromes are somew hat specific according to the stage of the disease (Table
1). This specificity reflects the distinct mechanisms of the various types of peripheral neuropathies in HIV seropositive individuals $5^{6 \cdot 11}$.

The prevalence of peripheral neuropathy associated with HIV-1 is estimated at 15 to $50 \%$ of patients ${ }^{7,12-15}$. But it may be almost $100 \%$ when a pathological study is performed ${ }^{14,15}$. Distal symmetrical polyneuropathy (DSP) is the most common peripheral nerve involvement in HIV-positive individuals ${ }^{3,16}$. There are other forms of peripheral neuropathies in HIV-positive patients including inflammatory demyelinating polyneuropathy ${ }^{6,17}$; progressive polyradiculopathy ${ }^{6,9}$; mononeuropathy and mononeuropathy multiplex ${ }^{10,18}$; autonomic neuropathy ${ }^{8}$;

Department of Neurology of Universidade Federal de São Paulo (UNIFESP), São Paulo SP, Brasil.

Received 3 September 2003. Accepted 3 December 2003.

Dra. Claudia Zanetti - Neurologia UNIFESP - Rua Botucatu 740 - 04023-900 São Paulo SP - Brasil. E-mail: zanettic@bol.com.br 
and diffuse infiltrative lymphocytosis syndrome ${ }^{19}$ (Table 1).

The objective of this study was to evaluate the frequency of peripheral neuropathy in a group of HIV-seropositive outpatients in São Paulo, Brazil.

\section{METHOD}

Over a period of 17 months, from July 1999 to M ay 2000, 49 HIVpositive patients where evaluated at the AIDS Outpatient Clinic of the Infectious Diseases Division of the UNIFESP - Escola Paulista de Medicina in São Paulo, Brazil.

Each patient arbitrarily recruited by the Coordinating Nurse had a history taken and neurological examination done by the same neurologist, mostly looking for the diagnosis of a peripheral neuropathy. Although highly suspicious of a peripheral neuropathy, symptoms of extremity pain, numbness, tingling and weakness were not enough to make the diagnosis. The diagnosis was established when we found any of the following, isolated or combined: sensory impairment, absent deep tendon reflexes, amyotrophy and weakness. We examined thermal, tactile, pain, vibration and position sense sensory modalities. Weakness was considered diagnostic if it had a pattern compatible with any form of peripheral neuropathy ${ }^{20}$. Laboratory analysis (glucose, CBC, BUN, creatinine, electrolytes, liver function, vita$\min B 12, V D R L, H T L V 1 / 2$ ) and electroneuromyography ${ }^{21}$ were requested to all patients.
The present study was approved by the ethics committee of the UNIFESP - Escola Paulista de M edicina. Informed consent was obtained from all patients.

\section{RESULTS}

Of the 49 patients included, 32 were male and 17 female. The mean age was 36.88 years with a range of 21-53 years. None of the patients had history of familial peripheral neuropathy, diabetes mellitus or recent (less than 2 years) history of alcohol abuse. Thirty four of our 49 patients $(69.4 \%)$ had diagnosis of a peripheral neuropathy. Twelve (35.3\%) had both symptoms and signs and 22 had only signs. Decreased distal superficial sensibility was the common sign occurring in $73.5 \%$ of the patients, one (3\%) had only absent ankle jerks and $8(23.5 \%)$ had sensibility and tendon reflexes altered. Two patients had only symptoms and two had sub-clinical peripheral neuropathy with neither symptoms nor signs - the peripheral neuropathy was diagnosed by the neurophysiologic study. Thirty two (94.1\%) patients were taking drugs supposed to be neurotoxic ( $d 4 \mathrm{~T}, \mathrm{ddl}, \mathrm{ddC}$, isoniazid) ${ }^{22-25}$. Thirty nine patients had electroneuromyography performed. Thirteen $(33.3 \%)$ of those had features of peripheral neuropathy. The types of peripheral neuropathy are shown in Table 2 . Seventy five per-

Table 1. Summary of HIV-associated peripheral neuropathies, clinical manifestations and diagnosis*.

\begin{tabular}{|c|c|c|c|c|}
\hline Diagnosis & HIV disease stage & Clinical symptoms & Neurological signs & Diagnostic studies \\
\hline $\begin{array}{l}\text { Distal symmetric } \\
\text { polyneuropathy }\end{array}$ & Late & $\begin{array}{l}\text { Dystal symmetric } \\
\text { numbness, tingling } \\
\text { and burnig sensations; } \\
\text { paresthesias or aching }\end{array}$ & $\begin{array}{l}\text { Stocking-glove sensory } \\
\text { loss; depressed or } \\
\text { absent ankle reflex }\end{array}$ & $\begin{array}{l}\text { EM G: distal axono } \\
\text { pathy }\end{array}$ \\
\hline $\begin{array}{l}\text { Inflammatory } \\
\text { demyelinating } \\
\text { polyneuropathy }\end{array}$ & Early $>>$ Late & $\begin{array}{l}\text { Progressive weakness; } \\
\text { paresthesias }\end{array}$ & $\begin{array}{l}\text { Muscle weakness; } \\
\text { mild sensory loss; } \\
\text { areflexia }\end{array}$ &  \\
\hline Mononeuritis multiplex & $\begin{array}{l}\text { Early (limited) } \\
\text { Late (progressive) }\end{array}$ & $\begin{array}{l}\text { Foot or wrist drop; } \\
\text { facial weakness; } \\
\text { focal pain }\end{array}$ & $\begin{array}{l}\text { Multifocal cranial } \\
\text { and peripheral } \\
\text { neuropathies }\end{array}$ & $\begin{array}{l}\text { EMG: multifocal } \\
\text { axonal neuropathies }\end{array}$ \\
\hline $\begin{array}{l}\text { Progressive } \\
\text { polyradiculopathy }\end{array}$ & Late & $\begin{array}{l}\text { Lower extremity } \\
\text { weakness; sphincter } \\
\text { dysfunction; } \\
\text { paresthesias }\end{array}$ & $\begin{array}{l}\text { Flaccid paraparesis; } \\
\text { saddle distribution } \\
\text { anesthesia; depressed } \\
\text { ankle and knee } \\
\text { reflexes }\end{array}$ & $\begin{array}{l}\text { CSF: increased PM Ns; } \\
\text { EM G: poliradiculopathy }\end{array}$ \\
\hline Autonomic neuropathy & Early $>>$ Late & $\begin{array}{l}\text { Orthostatic dizziness; } \\
\text { syncope; diarrhoea; } \\
\text { anhidrosis; palpitations; } \\
\text { impotence; urinary } \\
\text { dysfunction }\end{array}$ & $\begin{array}{l}\text { Orthostatic hypotension; } \\
\text { pupillary abnormalities; } \\
\text { sweating dysfuntion; } \\
\text { resting tachycardia }\end{array}$ & $\begin{array}{l}\text { ECG: arrhythmias; } \\
\text { blood pressure: } \\
\text { orthostatic hypotension }\end{array}$ \\
\hline
\end{tabular}

CSF, cerebrospinal fluid; ECG, electrocardiography; EM G, electromyography; PM Ns, polymorphonuclear leukocytes. * Reproducted from Wulff and Simpson ${ }^{29}$. 
cent (six patients) of the patients who had a diagnosis of DSP on electrophysiologic grounds were taking drugs supposed to be neurotoxic (d4T, ddl, ddC isoniazid) $)^{22-25}$. Laboratory analysis did not show any significant abnormalities (42 patients were tested), except in four who had VDRL positive.

\section{DISCUSSION}

To our knowledge this is the first study of the frequency of peripheral neuropathy in HIV-positive individuals in Brazil. In accordance with others ${ }^{26}$ we found that $69.4 \%$ of our patients had a clinical diagnosis of peripheral neuropathy, Interestingly, $64.7 \%$ of those did not have any complaint suggesting the involvement of the peripheral nervous system. That subclinical peripheral nerve dysfunction has been described ${ }^{5,27}$ and may reach $71 \%$ of those examined ${ }^{28}$. The most common complaints are numbness, parethesias and painful dysestesias $^{12,29}$. In our series the main symptom was mild distal dysestesia that neither interfered with the activities of daily living nor required specific therapy. The main neurological sign was distal symmetric sensory alteration (in $97.1 \%$ of the patients) in the four limbs but mainly in the feet.

Thirteen (33.3\%) of our 39 patients that had eletrophysiologic testing, had features of nerve lesion. The main eletrophysiologic diagnosis was sensitive-motor axonal neuropathy. In the literature DSP is responsible for $90 \%$ of the peripheral neuropathies in HIV-infected individuals $s^{3,12,13,16,30}$. Its incidence increases with advanced immunosupression and with decreased CD4-cell counts ${ }^{31}$, and thus more frequent in the later stages of the disease. DSP is clinically present in 10 to $35 \%$ of AIDS patients without known causes for their neuropathy ${ }^{12,13,16,32}$.


been described in $30-80 \%$ of patient $5^{5,12,13}$. Sensory symptoms predominate, and the patients complain of numbness and paresthesias. On neurological examination there is symmetric distal sensory loss with absent ankle reflexes ${ }^{12,29}$. Electrophysiological studies are most compatible with an axonal neuropathy ${ }^{12,30}$, the same as we found. There is a low incidence of DSP in pediatric HIV patients ${ }^{33}$.

We also found patients with mononeuropathy, mononeuropathy multiplex and demyelinating neuropathy (Table 2).

The etiology and pathogenesis of peripheral neuropathy associated with HIV infection is uncertain. It can be caused by the direct or indirect action of HIV and antibody production, or secondary to infections (CM V,M AC), toxic effects of certain drugs (isoniazid, vincristine, d4T, ddi, ddC), or nutritional deficiencies (vitamin B12) 4,7,22-26,34-36. In our study, almost all the patients that had diagnosis of peripheral neuropathy were taking drugs probably neurotoxic (ddi, $d 4 t$, ddC isoniazid).

Our electrophysiologic findings were much lower when compared to our clinical neurological evaluation. The discrepancy between our clinical and electrophysiologic findings is probably do to the well known poor evaluation of thin fiber system related to the routine nerve conduction tests ${ }^{37}$.

Peripheral neuropathy in HIV seropositive patients may be overlooked or misdiagnosed. A discerning clinical analysis may be helpful in the diagnosis of this common disease since

Table 2. Clinical manifestations, electroneuromyography and diagnosis.

\begin{tabular}{cccccccc}
\hline & Age & HIV/AIDS & Symptoms & Signs & ENMG & Evolution & Diagnosis \\
\hline 1 & 38 & HIV & no & no & axonal & & DSP \\
2 & 23 & AIDS & yes & S/M & axonal & sub-acute & DSP \\
3 & 30 & AIDS & yes & S & axonal & chronic & DSP \\
4 & 35 & AIDS & yes & S/M & axonal & chronic & DSP \\
5 & 38 & AIDS & no & S & axonal & & DSP \\
6 & 43 & HIV & yes & S & axonal & sub-acute & DSP \\
7 & 47 & AIDS & yes & no & axonal & & DSP \\
8 & 35 & AIDS & no & S/M & axonal & & DSP \\
9 & 38 & AIDS & yes & S & & chronic & MM \\
10 & 52 & HIV & yes & S/M & & chronic & MM \\
11 & 49 & HIV & yes & S & demyeliantin & chronic & IDP \\
12 & 39 & AIDS & yes & S & $?$ & chronic & M \\
13 & 49 & HIV & no & no & $?$ & & M \\
\hline
\end{tabular}

S, sensibility; M , motor; ENM G, electroneuromyography; DSP, distal symmetric polyneuropathy; IDP, inflammatory demyelinatin polyneuropathy; M M , mononeuropathy multiplex; $M$, mononeuropathy. 
the conventional electrophysiological study can underestimate some cases of peripheral nerve involvement.

\section{REFERENCES}

1. Gotlieb MS, Schroff R, Schanker HM, et al. Pneumocystis carinii pneumonia and mucosal candidiasis in previously healthy homosexual men. N Engl J Med 1981;305:1425-1431.

2. Horowitz SL, Benson DF, Gottlieb MS, Davos I, Bentson JR. Neurological complications of gay immunodeficiency disorder. Ann Neurol 1982;12:80.

3. Snider WD, Simpson DM, Nielsen S, Gold JWM, Metroka CE, Posner JB. Neurological complications of acquired immunodeficiency syndrome: analysis of 50 patients. Ann Neurol 1983;14:403-418.

4. Rizzuto N, Cavallaro T, Monaco S, et al. Role of HIV in the pathogenesis of distal symmetrical peripheral neuropathy. Acta Neuropathol (Berl) 1995;90:244-50.

5. Bacellar H, Muñoz A, Miller EN, et al. Temporal trends in the incidence of HIV-1-related neurologic diseases: multicenter AIDS cohort study, 1985-1992. Neurology 1994;44:1892-1900.

6. Simpson DM, Olney RK. Peripheral neuropathies associated with human immunodeficiency virus infection. Neurol Clin 1992;10:685-711.

7. Dalakas MC, Pezeshkpour GH. Neuromuscular diseases associated with human immunodeficiency virus infection. Ann Neurol 1988;23(suppl):S38-S48.

8. Cohen JA, Laudenslager M. Autonomic nervous system involvement in patients with human immunodeficiency virus infection. Neurology 1989:39:1111-1112.

9. Eidelberg D, Sotrel A, Vogel H, Walker P, Kleefield J, Crumpacker CS. Progressive polyradiculopathy in acquired immune deficiency syndrome. Neurology 1986;36:912-916.

10. So YT, Olney RK. The natural history of mononeuropathy multiplex and simplex in patients with HIV infection. Neurology 1991;41(Suppl 1):375.

11. Bradley W, Shapshak P, Delgado S, Nagano I, Stewart R, Rocha B. Morphometric analysis of the peripheral neuropathy of AIDS. Muscle Nerve 1998;21:1188-1195.

12. Cornblath DR, McArthur JC. Predominantly sensory neuropathy in patients with AIDS and AIDS-related complex. Neurology 1988;38:794-796.

13. So YT, Holtzman DM, Abrams DI, Olney RK. Peripheral neuropathy associated with acquired immunodeficiency syndrome: prevalence and clinical features from a population-based survey. Arch Neurol 1988;45:945-948.

14. de la Monte SM, Gabuzda DH, Ho DD, et al Peripheral neuropathy in the acquired immunodeficiency syndrome. Ann Neurol 1988;23:485-492.

15. Gabbai AA, Schmidt B, Castelo A, Oliveira ASB, Lima JGC. Muscle biopsy in AIDS and ARC: analysis of 50 patients. Muscle Nerve 1990;13:541544.

16. Fuller GN, Jacobs JM, Guiloff RJ. Nature and incidence of peripheral nerve syndromes in HIV infection. J Neurol Neurosurg Psychiatry 1993;56:372-381.

17. Parry O, Mielke J, Latif, AS, Ray S, Levy LF, Sizya S. Peripheral neuropathy in individuals with HIV infection in Zimbabwe. Acta Neurol Scand 1997;96:218-222.

18. Wechsler AF, Ho DD. Bilateral Bell's palsy at the time of HIV seroconversion. Neurology 1989;39:747-748.

19. Moulignier A, Authier F-J, Baudrimont M, et al. Peripheral neuropathy in human immunodeficiency virus-infected patients with diffuse infiltrative lymphocytosis syndrome. Ann Neurol 1997;41:438-445.

20. DeJongs. The neurologic examination. 5.Ed. Philadelphia: AF Haerer, 1999.

21. Kimura J. Electrodiagnosis in diseases of nerve and muscle; principles and practice 2.Ed. Philadelphia. Davis, 1988.

22. Figg WD. Peripheral neuropathy in HIV patients after isoniazid therapy. Drug Intell Clin Pharm 1991;25:100-101.

23. Browne MJ, Mayer KH, Chafee SBD, et al. 2', 3'-didehydro-3'deoxythymidine (d4T) in patients with AIDS and AIDS-related complex: a phase I trial. J Infect Dis 1993;167:21-29.

24. Pike IM, Nicaise C. The didanosine expanded access program: safety analysis. Clin Infect Dis 1993;16(Suppl 1):S63-S68.

25. Abrams DI, Goldman AI, Launer C, et al. A comparative trial of didano- sine or zalcitabine after treatment with zidovudine in patients with human immunodeficiency virus infection. N Engl J Med 1994;330:657-662.

26. Kieburtz KD, Giang DW, Shiffer RB, Vakil N. Abnormal vitamin B12 metabolism in human immunodeficiency virus infection: association with neurological dysfunction. Arch Neurol 1991;48:312-314.

27. Gastaut JL, Gastaut JA, Pelissier JF, Tapko JB, Weill O. Neuropathies with HIV infection, prospective study of 56 cases. Rev Neurol (Paris) 1989;145:451-459.

28. Marra CM, Boutin P, Collier AC. Screening for distal sensory peripheral neuropathy in HIV-infected persons in research and clinical settings. Neurology 1998;51:1678-1681.

29. Wulff EA, Simpson DM. HIV-associated neuropathy: recent advances in management. HIV Adv Res Ther 1998;8:23-29.

30. Miller RG, Parry CJ, Pfaeffl W, Lang W, Lippert R, Kiprov D. The spectrum of peripheral neuropathy associated with ARC and AIDS. Muscle Nerve 1988;11:857-863.

31. Lange DJ. Neuromuscular diseases associated with HIV-1 infection. Muscle Nerve 1984;17:16-30.

32. de Gans J, Portegies P. Neurological complications of infection with human immunodeficiency virus type 1: a review of literature and 241 cases. Clin Neurol Neurosurg 1989;91:199-219.

33. Lacroix C, Vazeux R, Brousse N, Blanche S, Tardieu M. A neuropathological study of 10 HIV-infected children. Rev Neurol (Paris) 1993;149:37-45.

34. Norton GR, Sweeney J, Marriott D, Law MG, Brew BJ. Association between HIV distal symmetric polyneuropathy and Mycobacterium avium complex infection. J Neurol Neurosurg Psychiatry 1996;61:606-609.

35. Gill P, Rarick M, Bernstein-Singer M, et al. Treatment of advanced Kaposi's sarcoma using combination of bleomycin and vincristine. Am J Clin Oncol 1990;13:315-319.

36. Simpson DM, Tagliati M. Nucleoside analogue-associated peripheral neuropathy in human immunodeficiency virus infections. J Acquir Immune Def Syndr Hum Retrovirol 1995;9:153-161.

37. Dumitru D. Electrodiagnostic medicine. Philadelphia:Hanley \& Belfus, 1995:111-209. 